\title{
ASSESSING Bemisia tabaci (GENN.) BIOTYPE B RESISTANCE IN SOYBEAN GENOTYPES: ANTIXENOSIS AND ANTIBIOSIS
}

\author{
José Paulo Gonçalves Franco da Silva ${ }^{1^{*}}$, Edson Luiz Lopes Baldin ${ }^{1}$, Efrain Santana de Souza ${ }^{1}$, \\ and André Luiz Lourenção ${ }^{2}$
}

Since it was first reported in Brazil in the 1990s, the B biotype of silverleaf whitefly (Bemisia tabaci [Genn.], Hemiptera: Aleyrodidae) has been recognized as an important pest in soybeans (Glycine max L.), reducing the productivity of this legume species in some areas of the country. As an alternative to chemical control, the use of resistant genotypes represents an important tool for integrated pest management (IPM). This study evaluated the performance of 10 soybean genotypes prior to whitefly infestation, by testing attractiveness and preference for oviposition in the greenhouse and antibiosis in the laboratory. In a multiple-choice test, 'IAC-17' was the least attractive to insects. In a no-choice test, 'IAC-17' was the least attractive for egg deposition, indicating the occurrence of non-preference for oviposition on this genotype. Trichome density was positively correlated with the oviposition site and may be associated with the resistance of 'IAC-17' to infestation The genotypes 'IAC-PL1', 'IAC-19', 'Conquista', 'IAC-24' and 'IAC-17' extended the insect's life cycle, indicating the occurrence of a small degree of antibiosis and/or non-preference for feeding.

Key words: Glycine max, silverleaf whitefly, host plant resistance, attractiveness, non-preference, trichome.

$S^{\circ}$ oybean (Glycine $\max$ L.) is one of the main agricultural crops in Brazil, occupying an area of approximately 24 million hectares in 2011/2012 (Conab, 2012). Although the area cultivated with this crop is increasing in the country, pest insects continue to harm productivity in the field, requiring constant attention from producers and researchers.

Bemisia tabaci (Genn.) B biotype is one of the most serious agricultural pests worldwide. It is highly polyphagous, is capable of causing various physiological disorders, and is a vector of viruses that attack many crops of economic interest, generating losses of millions of dollars per year (Perring et al., 1993; Polston and Anderson, 1999).

In Brazil, B. tabaci has been a sporadic problem in the soybean crop for a long time; however, with the arrival of the relatively aggressive biotype B in the 1990s (Lourenção and Nagai, 1994), the soybean has become a major host (Lima and Lara, 2004). While sucking the sap of the soybean plant, this whitefly excretes a sugar solution (honey dew), leading to development of

${ }^{1}$ Universidade de São Paulo, Facultade de Ciencias Agronómicas, Botucatu, São Paulo, Brasil.

*Corresponding author (jpgfdsilva@gmail.com).

${ }^{2}$ Instituto Agronomico de Campinas, Centro de Pesquisa e Desenvolvimento de Fitossanidade, Entomologia, Campinas, São Paulo, Brasil.

Received: 11 May 2012.

Accepted: 25 September 2012. colonies of fungi (Capnodium sp.) capable of reducing the photosynthetic capacity of the plant, also reducing its productivity (Ferreira and Ávidos, 1998).

Chemical control using synthetic insecticide sprays remains the most commonly used method for the management of whitefly populations in soybean (Vieira et al., 2011). However, this practice is constantly being reassessed, due to the imbalance that may arise in the environment and its negative impact on natural enemies. In addition, successive applications of the same insecticide, coupled with the insect's high capacity for reproduction, dispersal, and development, increase the chance that the insect will develop resistance against certain active principles (Prabhaker et al., 1985; Dittrich et al., 1990; Oliveira and Silva, 1997; Silva et al., 2009).

In this context, research focusing on alternative methods to chemicals has been stimulated in the last few years, with an emphasis on varietal resistance. The use of resistant genotypes could be a valuable tool for the Integrated Management of whitefly in soybean, reducing pest populations and costs of cultivation, in addition to being compatible with other control strategies (Lara, 1991; Smith, 2005; Vendramim and Guzzo, 2009). Up until the present time, some studies have reported the occurrence of non-preference (antixenosis) in soybean genotypes on this same whitefly (Valle and Lourenção, 2002). However, the levels of resistance recorded are still unable to keep the plants completely free of infestation. In addition, there are few studies reporting the occurrence of antibiosis on B. tabaci biotype B, justifying the continuities of these 
investigations. In this work we evaluated the resistance of different genotypes of soybean, through attractiveness, preference for oviposition and antibiosis tests, aiming to detect resistance mechanisms to the whitefly, B. tabaci biotype $\mathrm{B}$.

\section{MATERIALS AND METHODS}

\section{Soybean genotypes}

Ten soybean genotypes were evaluated (Table 1) prior to infestation with $B$. tabaci biotype $\mathrm{B}$, using greenhouse and laboratory tests. The genotypes 'IAC-17', 'IAC-19' and 'IAC-24' were selected since they were previously shown to be less attractive to silverleaf whitefly (Valle and Lourenção, 2002; Vieira et al., 2011) and stink bugs (Nezara viridula L., Lourenção et al., 2000; Miranda et al., 2003; Piubelli et al., 2003). 'IAC-PL1' and 'PI 227687 ' were used as susceptible standards, according to results from previous studies (Valle and Lourenção, 2002). 'TMG-103RR', 'TMG-117RR', 'TMG-121RR' and 'BRS-242RR' are transgenic genotypes that are in the process of being launched onto the market. 'Conquista' is a standard genotype widely cultivated in Brazil and is resistant to various diseases of this crop (Embrapa, 2010).

\section{Stock-rearing of B.tabaci biotype B}

Insects were acquired from cultures maintained at the Agronomic Institute (IAC), following the identification of the adults by Dr. Judith K. Brown, University of Arizona, as $B$. tabaci biotype B. These insects were transferred to metal cages $(2.0 \times 2.5 \times 2.0 \mathrm{~m})$, the sides of which were coated with anti-aphid screen, and the roof was covered with plastic and shading. Each cage contained benches to support pots of kale, on which the insects were cultured. The monitoring of the pots and the replacement of damaged plants with healthy ones was carried out weekly. Adults from this culture have recently been characterized molecularly, confirming that they belong to this biotype (Fontes et al., 2010; Valle et al., 2011).

\section{Tests of attractiveness and preference for oviposition in the greenhouse}

In a multiple-choice test, containers with a capacity of $2 \mathrm{~L}$, containing plants of 10 genotypes in stage V2-V3
(Fehr and Caviness, 1977), were randomly distributed (spaced at $5-10 \mathrm{~cm})$ in a circle in metal cages $(1.0 \mathrm{~m} \times 1.0$ $\mathrm{m} \times 0.8 \mathrm{~m})$ coated on all sides with anti-aphid screen. The experimental design was a randomized block design, with eight replicates.

Fifty pairs of whitefly (up to 48 h of age) per pot were released on the floor of the cage, towards the center. Attractiveness was evaluated 24 and $48 \mathrm{~h}$ after release, by counting with the aid of a mirror, the number of adults present on the abaxial surface of three previously tagged leaflets (upper, middle and bottom thirds of the plant).

After $72 \mathrm{~h}$ of infestation, leaflets were again evaluated according to their attractiveness, and were then removed and taken to the laboratory where (under a $40 \mathrm{X}$ objective) the number of eggs on the abaxial surface of each of them was counted. The area of the leaflets was also measured using an area meter (LI-3100C, Li-Cor, Lincoln, Nebraska, USA), in order to calculate the number of egg $\mathrm{cm}^{-2}$.

In no-choice tests, pots of plants of the same soybean genotype (V2-V3) were individualized, connecting to the surrounding metal hoops involved with "voile" tissue (Baldin et al., 2005). Then, 50 pairs of whitefly (up to $48 \mathrm{~h}$ of age) were released per pot and after $72 \mathrm{~h}$, three previously marked leaves per plant were evaluated for oviposition, following the methodology described for the free-choice test. Eight replicates were set up in a completely randomized design. The index of preference for oviposition (IPO) (Baldin et al., 2005; Schlick-Souza et al., 2011) was also calculated, based on the formula: $\mathrm{IPO}=[(\mathrm{T}-\mathrm{P}) /(\mathrm{T}+\mathrm{P})] \times 100$, where $\mathrm{T}=$ number of eggs in evaluated treatment and $\mathrm{P}=$ number of eggs in standard genotype ('Conquista').

\section{Tests of antibiosis in the laboratory}

Antibiosis was evaluated in the laboratory under controlled conditions (RH $70 \pm 10 \% ; \mathrm{T}=26 \pm 2{ }^{\circ} \mathrm{C}$ and photoperiod 12:12 h). The genotypes were sown in pots $(2.0 \mathrm{~L})$ containing soil and organic substrate (Plantmax $\mathrm{HA}^{\mathrm{TM}}$, DDL Agroindústria Ltda., Paulínia, São Paulo, Brasil) and remained free of infestation by the whitefly up to $30 \mathrm{~d}$ of age. Three leaflets per plant (one for each third) were individualized, connecting to cages made of voile fabric, into which were released 25 pairs of insects $(48 \mathrm{~h}$ of age). After $24 \mathrm{~h}$, insects were removed from leaflets,

Table 1. Soybean genotypes evaluated for resistance to Bemisia tabaci biotype B with their genealogies and origins.

\begin{tabular}{|c|c|c|}
\hline Genotype & Genealogy & Origin \\
\hline 'IAC-17' & D72-9601-1 × IAC-8 & IAC-Campinas, SP \\
\hline 'IAC-19' & D72-9601-1 $\times$ IAC-8 & IAC-Campinas, SP \\
\hline 'IAC-24' & IAC $80-1177 \times$ IAC83-288 & IAC-Campinas, SP \\
\hline 'IAC-PL1' & Mutation of Japanese material for a later cycle & IAC-Campinas, SP \\
\hline 'PI-227687' & Okinawa, Japan & IAC-Campinas, SP \\
\hline 'Conquista' & Lo76-4484² ×Numbaíra & FMT-Rondonópolis, MT \\
\hline 'TMG-103RR' & TMGLM-3295 × TMGLM-3324 & FMT-Rondonópolis, MT \\
\hline 'TMG-117RR' & $($ FT Corvina $\times$ Msoy beans $8888 \mathrm{RR}) \times \mathrm{MG} / \mathrm{BR} 46$ & FMT-Rondonópolis, MT \\
\hline 'TMG-121RR' & (FMT Cachara×Msoy beans $8080 \mathrm{RR}) \times$ FMT Tucunaré & FMT-Rondonópolis, MT \\
\hline 'BRS-242RR' & Embrapa $58 * 5 ' \times($ E96-246 ×Embrapa 59) & EMBRAPA, Londrina, PR \\
\hline
\end{tabular}

IAC: Instituto Agronômico de Campinas, São Paulo; FMT: Fundação Mato Grosso, Mato Grosso; SP: São Paulo; MT: Mato Grosso; PR: Paraná. 
and an area with only 30 eggs on the abaxial surface of each of them was delimited using glitter. Each leaflet (containing 30 eggs) represented one replicate, totaling three per genotype, in a completely randomized design. As the period of emergence approached, leaflets were again placed in voile cages to prevent the escape of adults, which were evaluated for longevity.

Assessments were conducted daily, recording incubation period, duration and mortality of nymphal instars, period of development from egg to adult, larval viability and longevity of adults without feeding. To assess longevity, 15 newly emerged individuals (five from each leaflet) were placed in glass containers and kept in BOD incubator (EL 202, Eletrolab, São Paulo, São Paulo, Brasil) (same environmental conditions as in the laboratory).

\section{Trichome density}

With the aim of correlating oviposition with morphological features of the 10 genotypes of soybean, we evaluated the number of trichomes present in $16 \mathrm{~mm}^{2}$ of the abaxial surface of leaflets of each genotype (under a 40X objective), as described by Valle and Lourenção (2002). We analyzed leaflets from the upper, middle, and lower strata of plants, at the same stages of development as those used for assessments of attractiveness and preference for oviposition. We used four plants of each genotype, from which were removed three leaflets each (one for each stratum), totaling 12 leaflets per genotype. A completely randomized design was used with 10 genotypes and four replicates per stratum, totaling 40 plots. Each plot consisted of a soybean leaf and each observation was the average number of trichomes present in the basal and apical portions of each leaflet (adapted from McAuslane, 1996).

\section{Statistical analyses}

Data obtained from all experiments were analyzed by one-way ANOVA; prior to analysis the original data (x) were transformed to $(x+0.5)^{1 / 2}$ or arc sine $(x / 100)^{1 / 2}$. Tukey's HSD test was used to compare means (Winer et al., 1991). Statistical analyses were performed using the PROC GLM procedure of SAS (SAS Institute, 2001).

\section{RESULTS AND DISCUSSION}

\section{Tests of attractiveness and preference for oviposition in the greenhouse}

In the multiple-choice test (Table 2), the genotype 'IAC17 ' stood out as the least attractive in the 24-h evaluation after infestation, differing significantly from 'IAC-19' and 'IAC-24'. There was no difference among genotypes in the second evaluation (48 h).

These results suggest the occurrence of non-preference for 'IAC-17', and corroborate the results of Valle and Lourenção (2002). In a similar study, Vieira et al. (2011) found low attractiveness in the genotypes 'IAC-17', 'IAC-
Table 2. Mean ( $\pm \mathrm{SE})$ number of adults, eggs per $\mathrm{cm}^{2}$ of Bemisia tabaci $B$ biotype, oviposition preference index (OPI) and classification of soybean genotypes in multi-choice test under greenhouse conditions.

\begin{tabular}{lcrc}
\hline Genotype & $\mathrm{N}^{\circ}$ adults $(24 \mathrm{~h})$ & $\mathrm{N}^{\circ}$ adults $(48 \mathrm{~h})$ & $\mathrm{N}^{\circ}$ eggs cm \\
\hline 'IAC-17' & $8.08 \pm 2.17 \mathrm{~b}$ & $9.67 \pm 2.56 \mathrm{a}$ & $1.52 \pm 0.61 \mathrm{a}$ \\
'TMG-117 RR' & $13.42 \pm 2.32 \mathrm{ab}$ & $9.46 \pm 2.56 \mathrm{a}$ & $6.37 \pm 3.09 \mathrm{a}$ \\
'TMG-121 RR' & $14.67 \pm 2.55 \mathrm{ab}$ & $12.92 \pm 2.44 \mathrm{a}$ & $4.66 \pm 1.79 \mathrm{a}$ \\
'BRS-242 RR' & $14.92 \pm 2.42 \mathrm{ab}$ & $14.96 \pm 3.20 \mathrm{a}$ & $3.64 \pm 1.88 \mathrm{a}$ \\
'TMG-103 RR' & $15.79 \pm 4.43 \mathrm{ab}$ & $11.15 \pm 2.58 \mathrm{a}$ & $3.74 \pm 1.29 \mathrm{a}$ \\
'IAC-PL1' & $21.00 \pm 5.10 \mathrm{ab}$ & $18.42 \pm 4.68 \mathrm{a}$ & $3.73 \pm 1.63 \mathrm{a}$ \\
'PI-227687' & $21.58 \pm 4.96 \mathrm{ab}$ & $22.38 \pm 3.94 \mathrm{a}$ & $8.08 \pm 2.60 \mathrm{a}$ \\
'Conquista' & $23.08 \pm 4.80 \mathrm{ab}$ & $15.25 \pm 3.57 \mathrm{a}$ & $2.89 \pm 0.78 \mathrm{a}$ \\
'IAC-19' & $24.67 \pm 5.36 \mathrm{a}$ & $23.96 \pm 4.83 \mathrm{a}$ & $5.05 \pm 1.83 \mathrm{a}$ \\
'IAC-24' & $28.96 \pm 4.81 \mathrm{a}$ & $22.25 \pm 4.80 \mathrm{a}$ & $7.94 \pm 2.86 \mathrm{a}$ \\
$\mathrm{F}$ & $2.97 *$ & $2.26^{\mathrm{ns}}$ & $1.35^{\mathrm{ns}}$ \\
CV $(\%)$ & 29.26 & 33.14 & 83.01
\end{tabular}

Means followed by the same lower case letter in each column do not differ according to Tukey test $(\mathrm{P}<0.05)$. For analysis, original data were transformed to $(x+0.5)^{1 / 2}$. $\mathrm{CV}$ : coefficient of variation; ${ }^{\text {ns: }}$ Non significant.

19', 'BRS Gralha', 'Barreiras', 'Corisco', 'BABR011259', and 'BABR99-4021 HP'.

There was no significant difference in the average number of eggs deposited in a multiple-choice test (Table 2). However, in absolute terms, the lowest average was recorded in 'IAC-17'. Lower oviposition was expected in this genotype, since its leaves were less attractive to whitefly adults, and previous studies have shown a positive correlation between adult attractiveness and oviposition for B. tabaci biotype B in soybean and potato (Solanum spp., Valle and Lourenção, 2002; Silva et al., 2008). In a similar study, Torres et al. (2007) reported that cotton (Gossypium hirsutum L.) genotypes 'BRS Aroeira', 'BRS Verde', and 'BRS Ita 90-2' were the least oviposited upon by the same whitefly. In tomato (Solanum lycopersicum L.), studies using different genotypes showed that 'LA-716', 'LA444-1' and 'PI 134418' were the least attractive to whitefly adults; 'LA 716' also stood out as the least oviposited upon (Baldin et al., 2005; Oriani and Vendramim, 2010).

In the no-choice test (Table 3), the genotype 'IAC-17' was the least oviposited upon, differing from the other genotypes and indicating the occurrence of resistance via non-preference for oviposition.

Table 3. Mean ( \pm SE) number of eggs per $\mathrm{cm}^{2}$ of Bemisia tabaci B biotype, oviposition preference index (IPO) and classification of soybean genotypes in no-choice test under greenhouse conditions.

\begin{tabular}{lcrl}
\hline Genotype & $\mathrm{N}^{\circ}$ eggs $^{1} \mathrm{~cm}^{-2}$ & \multicolumn{1}{c}{$\mathrm{OPI}( \pm \mathrm{SE})^{2}$} & Classification $^{2}$ \\
\hline 'IAC-17' & $2.53 \pm 0.77 \mathrm{~b}$ & $-26.59 \pm 18.39$ & Deterrent \\
'IAC-19' & $4.16 \pm 1.31 \mathrm{ab}$ & $-5.53 \pm 18.39$ & Neutral \\
'TMG-103 RR' & $4.36 \pm 0.88 \mathrm{ab}$ & $7.07 \pm 18.39$ & Neutral \\
'IAC-PL1' & $4.46 \pm 1.40 \mathrm{ab}$ & $1.19 \pm 18.39$ & Neutral \\
'IAC-24' & $5.15 \pm 1.09 \mathrm{ab}$ & $12.81 \pm 18.39$ & Neutral \\
'TMG-117 RR' & $5.66 \pm 1.72 \mathrm{ab}$ & $10.17 \pm 18.39$ & Neutral \\
'Conquista' & $5.73 \pm 2.68 \mathrm{ab}$ & $0.00 \pm 18.39$ & Standard \\
'TMG-121 RR' & $5.74 \pm 1.53 \mathrm{ab}$ & $13.50 \pm 18.39$ & Neutral \\
'BRS-242 RR' & $6.31 \pm 1.36 \mathrm{ab}$ & $22.43 \pm 18.39$ & Stimulant \\
'PI-227687' & $10.27 \pm 2.12 \mathrm{a}$ & $38.87 \pm 18.39$ & Stimulant \\
F & $1.78 *$ & - & - \\
CV $(\%)$ & 36.96 & - & - \\
\hline
\end{tabular}

${ }^{1}$ Means followed by the same lower case letter in each column do not differ according to Tukey test $(\mathrm{P}<0.05)$. For analysis, original data were transformed to $(x+0.5)^{1 / 2}$

${ }^{2} \mathrm{IPO}=[(\mathrm{T}-\mathrm{P}) /(\mathrm{T}+\mathrm{P})] \times 100$. IPO ranged from +100 (very stimulant) to -100 (total deterrence), and the value 0 indicated neutrality.

$\mathrm{CV}$ : coefficient of variation. 
In contrast, 'PI-227687' showed the highest rate of oviposition, proving to be more susceptible to oviposition by whitefly in this type of test. Similar results were reported by Rossetto et al. (1977), who also found susceptibility in 'PI 227687' in relation to the oviposition rate of whitefly. The genotype 'BRS-242 RR' was considered to stimulate the oviposition of whitefly, whereas the others were classified as neutral compared to 'Conquista'.

The low rate of oviposition observed on 'IAC-17' leads to the recommendation to plant this genotype in regions in which B. tabaci biotype B significantly affects the production of soybeans or other crops (beans, tomatoes, green vegetables) grown simultaneously or in rotation with soybean. The use of this genotype in association with other control strategies could reduce infestations and damage caused by this whitefly, favoring the optimal production of soybeans and other crops affected by this pest.

\section{Tests of antibiosis in the laboratory}

The average incubation period did not differ amongst genotypes, being about $6 \mathrm{~d}$ in all cases. With regard to the nymphal stages of the whitefly, there were differences between genotypes for all instars (Table 4). The genotype 'IAC-24' extended the first nymphal instar in relation to the other genotypes. The duration of the second instar was longest on 'Conquista', differing significantly from 'BRS242 RR'. The duration of the third instar was longest on 'BRS-242 RR', which differed from the genotypes 'IACPL1', 'IAC-19', 'TMG-103 RR' and 'PI 227687'. In the fourth instar, 'IAC-19' and 'IAC-PL1' induced the longest period of development, differing significantly from the other genotypes. The averages for the total duration of egg-adult development of whitefly on the soybean genotypes ranged from 19.31 to 21.35 d. 'IAC-PL1' produced the highest average, differing significantly from 'TMG-103 RR' and 'TMG-117 RR'. 'IAC-17', 'IAC19', 'IAC-24' and 'Conquista' produced intermediate averages, but also extended the cycle in relation to 'MRF103 RR', the most susceptible genotype. The extension of nymphal stages in 'IAC-PL1', 'IAC-17', 'IAC-19', 'IAC-24' and 'Conquista' may result from the small levels of resistance due to antibiosis and/or non-preference for feeding (Vendramim and Guzzo, 2009).

Among other explanations, this resistance may be the result of morphological features, such as epidermal thickness and/or biochemical factors, such as the concentrations of free amino acids, fatty acids and fiber present in the leaflets, which may have adverse effects on the insect and, in some way, affect the biological performance of the insect (Lara, 1991; Panda and Khush, 1995; Lima and Lara, 2004; Smith, 2005).

Although 'PI 227687' has stimulated studies on the resistance of soybean to insects after being identified as the bearer of multiple resistance (Van Duyn et al., 1971; Clark et al., 1972; Smith, 1985; Beach and Todd, 1988), this material was described as the most favorable to the development of the nymphs of $B$. tabaci biotype B by Lima and Lara (2004). In the present study, this material was also favorable to the development of whitefly nymphs.

Regarding nymphal viability (Table 4), there was no significant difference between the genotypes, the averages of which varied between $74.70 \%$ ('IAC-PL1') and $88.81 \%$ ('TMG-103 RR').

\section{Trichome density}

Data on the number of trichomes (Figure 1) showed that the genotype PI 227687 has a trichome density significantly higher than that of the other genotypes. The high density of trichomes in this genotype, combined with the high number of eggs present in free-choice and nochoice tests, suggests that these structures encourage or stimulate the permanence and oviposition of the insect on the plant. This has already been reported by Valle and Lourenção (2002), who found a high number of trichomes in 'PI 227687', which was one of the cultivars with the largest number of eggs $10 \mathrm{~cm}^{-2}$ in the free-choice test.

Lima and Lara (2004) also found a higher density of trichomes and eggs on 'PI 227687', 'BR-82 12547'

Table 4. Means $( \pm \mathrm{SE})$ of nymphal stages, total period (egg-adult) and nymphal viability (\% $\pm \mathrm{SE}$ ) of Bemisia tabaci B biotype in soybean genotypes under laboratory conditions $\left(\mathrm{T}=25 \pm 2{ }^{\circ} \mathrm{C} ; \mathrm{RH}=70 \pm 10 \%\right.$; photoperiod $\left.12: 12 \mathrm{~h}\right)$.

\begin{tabular}{|c|c|c|c|c|c|c|}
\hline \multirow[b]{2}{*}{ Genotypes } & \multicolumn{5}{|c|}{ Duration (d) } & \multirow[b]{2}{*}{ Viability $(\%)^{1}$} \\
\hline & $1^{\text {st }}$ instar & $2^{\text {nd }}$ instar & $3^{\text {rd }}$ instar & $4^{\text {th }}$ instar & Total period & \\
\hline 'IAC-24 & $1.61 \pm 0.10 \mathrm{a}$ & $2.58 \pm 0.10 \mathrm{ab}$ & $4.00 \pm 0.20 \mathrm{ab}$ & $6.32 \pm 0.12 b$ & $20.54 \pm 0.20 \mathrm{ab}$ & $83.33 \pm 0.06 a$ \\
\hline 'TMG-121RR' & $1.40 \pm 0.10 \mathrm{ab}$ & $2.57 \pm 0.11 \mathrm{ab}$ & $4.07 \pm 0.25 \mathrm{ab}$ & $6.30 \pm 0.22 b$ & $20.34 \pm 0.08 \mathrm{abc}$ & $80.00 \pm 0.06 a$ \\
\hline 'PI-227687' & $1.36 \pm 0.08 \mathrm{ab}$ & $2.92 \pm 0.21 \mathrm{ab}$ & $3.13 \pm 0.32 b$ & $7.08 \pm 0.14 b$ & $20.48 \pm 0.14 a b c$ & $74.70 \pm 0.04 a$ \\
\hline 'IAC-17' & $1.29 \pm 0.17 \mathrm{ab}$ & $2.28 \pm 0.24 \mathrm{ab}$ & $3.53 \pm 0.13 \mathrm{ab}$ & $7.43 \pm 0.42 b$ & $20.53 \pm 0.37 \mathrm{ab}$ & $88.57 \pm 0.01 \mathrm{a}$ \\
\hline 'TMG-103RR' & $1.21 \pm 0.10 \mathrm{ab}$ & $2.62 \pm 0.40 \mathrm{ab}$ & $3.09 \pm 0.20 b$ & $6.39 \pm 0.15 b$ & $19.31 \pm 0.25 c$ & $81.37 \pm 0.03 a$ \\
\hline 'TMG-117 RR' & $1.16 \pm 0.06 b$ & $2.78 \pm 0.10 \mathrm{ab}$ & $3.26 \pm 0.26 \mathrm{ab}$ & $6.80 \pm 0.12 b$ & $19.99 \pm 0.24 b c$ & $78.82 \pm 0.03 a$ \\
\hline 'Conquista' & $1.12 \pm 0.10 \mathrm{~b}$ & $3.26 \pm 0.35 a$ & $3.66 \pm 0.37 \mathrm{ab}$ & $6.87 \pm 0.22 b$ & $20.91 \pm 0.28 \mathrm{ab}$ & $81.60 \pm 0.01 \mathrm{a}$ \\
\hline 'BRS-242 RR' & $1.09 \pm 0.05 b$ & $2.10 \pm 0.10 b$ & $4.62 \pm 0.07 \mathrm{a}$ & $6.36 \pm 0.38 b$ & $20.17 \pm 0.41 \mathrm{abc}$ & $84.44 \pm 0.05 a$ \\
\hline 'IAC-19' & $1.00 \pm 0.00 \mathrm{~b}$ & $2.33 \pm 0.24 a b$ & $2.95 \pm 0.30 \mathrm{~b}$ & $8.68 \pm 0.21 \mathrm{a}$ & $20.97 \pm 0.13 \mathrm{ab}$ & $88.81 \pm 0.03 a$ \\
\hline 'IAC-PL1' & $1.00 \pm 0.00 \mathrm{~b}$ & $3.02 \pm 0.09 \mathrm{ab}$ & $2.86 \pm 0.41 b$ & $8.48 \pm 0.31 \mathrm{a}$ & $21.35 \pm 0.08 \mathrm{a}$ & $83.01 \pm 0.08 \mathrm{a}$ \\
\hline $\mathrm{F}$ & $5.42^{*}$ & $2.73^{*}$ & $4.04^{*}$ & $15.72^{*}$ & $5.46^{*}$ & $0.78^{\mathrm{ns}}$ \\
\hline $\mathrm{CV}(\%)$ & 4.09 & 5.96 & 6.08 & 2.49 & 1.01 & 9.54 \\
\hline
\end{tabular}

Means followed by the same lower case letter in each column do not differ according to Tukey test $(\mathrm{P}<0.05)$.

CV: coefficient of variation; ${ }^{\text {ns: }}$ Non significant.

${ }^{1}$ For analysis, data were transformed to $\operatorname{arcsen}(\mathrm{x} / 100)^{1 / 2}$ 
and 'PI 229358' had the lowest densities of trichomes and the fewest eggs. The positive correlation between the density of trichomes and the oviposition of whitefly has previously been found in other soybean genotypes (McAuslane et al., 1995; McAuslane, 1996) and also in cotton (Berlinger, 1986; Butter and Vir, 1989), and tomato (Heinz and Zalom, 1995).

According to Vieira et al. (2011), the high density and length of the trichomes present on leaves are fundamental to the colonization of whitefly, as they help individuals to remain on the surface of leaves and avoid being carried away by the wind. Other theories suggest that genotypes with a large number of trichomes can generate a microclimate that is more favorable to oviposition by B. tabaci (Butter and Vir, 1989), and that the females prefer ovipositing at the base of the trichomes (Omram and El-Khidir, 1978; Berlinger, 1986). In addition, this behavior could be an evolutionary response to the selection pressure exerted by predators and parasitoids, as these natural enemies are more effective on leaves that are less hairy or glabrous (Li et al., 1987; Butter and Vir, 1989).

The quantification of trichomes also revealed that 'Conquista', 'IAC-17', 'TMG-117' and 'TMG-103' have a low density of these structures. The correlation between the low density of trichomes of 'IAC-17' with its low attractiveness to whitefly adults and the low number of eggs $\mathrm{cm}^{-2}$ confirms the role of these structures in the

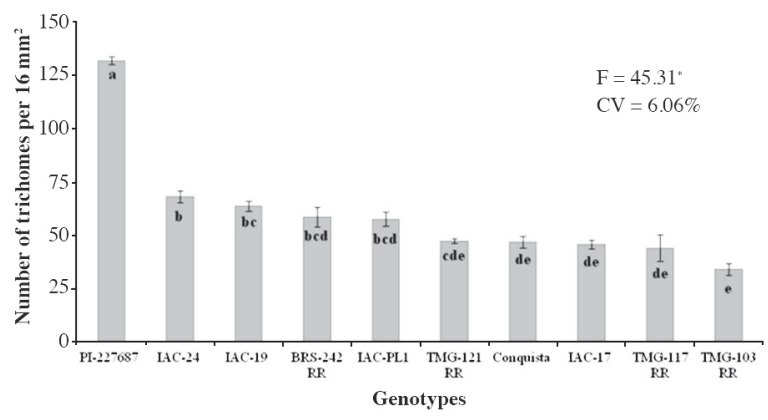

Figure 1. Mean number of trichomes $16 \mathrm{~mm}^{-2}$ on the abaxial surface of soybean leaves.

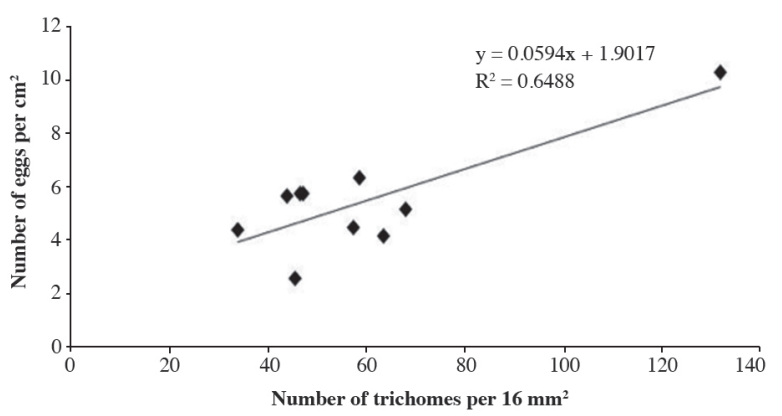

Figure 2. Correlation between number of trichomes and oviposition by Bemisia tabaci B biotype in soybean genotypes. colonization and oviposition of this insect on this plant. Figure 2, showing the correlation between the trichome density of different soybean varieties and the number of eggs of $B$. tabaci biotype B, clearly shows that as trichome density decreases, the rate of oviposition by whitefly adults also decreases.

\section{CONCLUSIONS}

In general, 'IAC-17' was the most resistant genotype against the silverleaf whitefly. The low density of trichomes on leaves of this genotype seems to be the main cause of its low attractiveness and high levels of non-preference for oviposition. The small extension in the whitefly life cycle observed in 'IAC-PL1', 'IAC-19', 'Conquista', 'IAC-24' and 'IAC-17' indicates the occurrence of small levels of non-preference for feeding and/or antibiosis in these genotypes; however, more detailed chemical and morphological analyses will be required to confirm this behavior and to identify the main factors involved. Given the increasing importance of B. tabaci biotype B for the soybean crop in Brazil, these results may be useful for soybean breeding programs aiming to develop genotypes that are resistant to this whitefly.

\section{ACKNOWLEDGEMENTS}

To the São Paulo Research Foundation - FAPESP (projects 07/50688-8 and 09/53977-6) for financial support. To the National Council for Scientific and Technological Development - CNPq for the Productivity in Research fellowship granted to the second and fourth authors.

Evaluación de la resistencia de genotipos de soya a Bemisia tabaci (GENN.) biotipo B: Antixenosis y antibiosis. Desde que se registró por primera vez en Brasil en la década de 1990, el biotipo B de la mosca-blanca (Bemisia tabaci [Genn.], Hemiptera: Aleyrodidae), se reconoce como una importante plaga de la soya (Glycine $\max$ L.) y es lo que reduce la productividad de estas especies de leguminosas en algunas zonas del país. Como una alternativa al control químico, el uso de genotipos resistentes representa una herramienta importante para la gestión integrada de plagas (MIP). Este trabajo evaluó el comportamiento de 10 genotipos de soya frente al ataque de la mosca-blanca, por medio de ensayos de atractividad y preferencia para ovipostura en invernaderos y antibiosis en laboratorio. En una prueba de elección múltiple, 'IAC-17' fue el menos atractivo para los insectos. En una prueba sin elección, 'IAC-17' fue el menos atractivo para la deposición de huevos, lo que indica la ocurrencia de no preferencia para ovipostura de este genotipo. La densidad de tricomas se correlacionó positivamente con el sitio de ovipostura y pueden estar asociados con la resistencia de 'IAC-17' a la infestación. Los genotipos 'IAC-PL1', 
'IAC-19', 'Conquista', 'IAC-24' y 'IAC-17' extendieron el ciclo de vida del insecto, lo que indica la aparición de un pequeño grado de antibiosis y/o no preferencias para la alimentación.

Palabras clave: Glycine max, mosca-blanca, resistencia de plantas, atractividad, no-preferencia, tricoma.

\section{LITERATURE CITED}

Baldin, E.L.L., J.D. Vendramin, and A.L. Lourenção. 2005. Resistance of tomato genotypes to the whitefly Bemisia tabaci (Gennadius) biotype B (Hemiptera: Aleyrodidae). Neotropical Entomology 34:435-441.

Beach, R.M., and J.W. Todd. 1988. Foliage consumption and developmental parameters of the soybean looper and the velvet bean caterpillar (Lepidoptera: Noctuidae) reared on susceptible and resistant soybean genotypes. Journal of Economic Entomology 81:310-316.

Berlinger, M.J. 1986. Host plant resistance to Bemisia tabaci. Agriculture, Ecosystems \& Environment 17:69-82.

Butter, N.S., and B.K. Vir. 1989. Morphological basis of resistance in cotton to the whitefly Bemisia tabaci. Phytoparasitica 17:251-261.

Clark, W.J., F.A. Harris, F.G. Maxwell, and E.E. Hartwig. 1972. Resistance of certain soybean cultivars to bean leaf beetle, striped blister and bollworm. Journal of Economic Entomology 65:16691672 .

Conab. 2012. Acompanhamento de safra brasileira: grãos, quarto levantamento, janeiro 2012. Companhia Nacional de Abastecimento (Conab), Brasília, 38 p. Março 2012. Available at http://www.conab.gov.br/OlalaCMS/uploads/ arquivos/12_01_10_10_53_02_boletim_graos_4o_levantamento. pdf (accessed March 2012).

Dittrich, V., G.H. Ernst, O. Ruesch, and S. Uk. 1990. Resistance mechanisms in sweet potato whitefly (Homoptera: Aleyrodidae) populations from Sudan, Turkey, Guatemala, and Nicaragua. Journal of Economic Entomology 83:1665-1670.

Embrapa. 2010. Soja Conquista resiste ao cancro da haste. Empresa Brasileira de Pesquisa e Agropecuária (Embrapa). 2010. Available at http://www.embrapa.br/imprensa/noticias/1996/julho/bn.200411-25.6692269003/ (accessed October 2010).

Fehr, W.R., and C.E. Caviness. 1977. Stages of soybean development. Special Report 80. Co-operative Extension Service. 11 p. Iowa State University, Ames, Iowa, USA

Ferreira, L.T., and M.F.D. Ávidos. 1998. Mosca-branca: presença indispensável no Brasil. Biotecnologia - Ciência \& Desenvolvimento 4:22-26.

Fontes, F.V.H.M., C.A. Colombo, and A.L. Lourenção. 2010. Caracterização molecular e divergência genética de Bemisia tabaci (Genn.) (Hemiptera: Aleyrodidae) em diferentes culturas e locais de cultivo. Neotropical Entomology 39:221-226.

Heinz, K.M., and F.G. Zalom. 1995. Variation in trichome-based resistance to Bemisia argentifolli (Homoptera: Aleyrodidae) oviposition on tomato. Journal of Economic Entomology 88:1494-1502.

Lara, F.M. 1991. Princípios de resistência de plantas a insetos. 336 p. Ícone, São Paulo, Brasil

Li, Z.H., F. Lammes, J.C. Van Lenteren, P.W.T. Huisman, A. Van Vianen, and O.M.B. De Ponti. 1987. The parasite-host relationship between Encarsia formosa Gahan (Hymenoptera: Aphelinidae) and Trialeurodes vaporariorum (Westwood) (Homoptera: Aleyrodidae). XXV. Influence of leaf structure on the searching activity of Encarsia formosa. Journal of Applied Entomology 104:297-304.

Lima, A.C.S., and F.M. Lara. 2004. Resistência de genótipos de soja à mosca-branca Bemisia tabaci (Genn.) biótipo B (Hemiptera: Aleyrodidae). Neotropical Entomology 33:71-75.
Lourenção, A.L., and H. Nagai. 1994. Surtos populacionais de Bemisia tabaci no Estado de São Paulo. Bragantia 53:53-59.

Lourenção, A.L., J.C.V.N.A. Pereira, M.A.C. Miranda, and G.M.B. Ambrosano. 2000. Avaliação de danos causados por percevejos e por lagartas em genótipos de soja de ciclo precoce e semiprecoce. Pesquisa Agropecuária Brasileira 35:879-886.

McAuslane, H.J. 1996. Influence of leaf pubescence on ovipositional preference of Bemisia argentifolii (Homoptera: Aleyrodidae) on soybean. Environmental Entomology 25:834-841.

McAuslane, H.J., F.A. Johnson, D.L. Colvin, and B. Sojack. 1995. Influence of foliar pubescence on abundance and parasitism of Bemisia argentifolii (Homoptera: Aleyrodidae) on soybean and peanut. Environmental Entomology 24:1135-1143.

Miranda, M.A.C., N.R. Braga, A.L. Lourenção, F.T.S., Miranda, S.H. Unêda, and M.F. Ito. 2003. Descrição, produtividade e estabilidade da cultivar de soja IAC-24, resistente a insetos. Bragantia 62:19-27.

Oliveira, M.R.V., and O.L.R. Silva. 1997. Prevenção e controle da mosca-branca Bemisia argentifolii (Hemiptera: Aleyrodidae). 16 p. Ministério da Agricultura e do Abastecimento, Departamento de Defesa e Inspeção Vegetal, Brasília, Brasil.

Omram, H.H., and R. El-Khidir. 1978. On the preference of Bemisia tabaci Genn. (Homoptera: Aleyrodidae) on various cotton cultivars in Cukurova, Turkey. Agriculture, Ecosystems \& Environment 17:83-88

Oriani, M.A.G., and J.D. Vendramim. 2010. Influence of trichomes on attractiveness and ovipositional preference of Bemisia tabaci (Genn.) B biotype (Hemiptera: Aleyrodidae) on tomato genotypes. Neotropical Entomology 39:1002-1007.

Panda, N., and G.S. Khush. 1995. Host plant resistance to insects. 448 p. Oxford University Press, Oxford, UK

Perring, T.M., A.D. Cooper, R.J. Rodriguez, C.A. Farrar, and T.S. Bellows Jr. 1993. Identification of a whitefly species by genomic and behavioral studies. Science 259:74-77.

Piubelli, G.C., C.B. Hoffmann-Campo, I.C. Arruda, and F.M. Lara. 2003. Nymphal development, lipid content, growth and weight gain of Nezara viridula (L.) (Heteroptera: Pentatomidae) fed in soybean genotypes. Neotropical Entomology 32:127-132.

Polston, J.E., and P.K. Anderson. 1999. Surgimiento y distribución de Geminivirus transmitidos por mosca blanca en tomate en el Hemisferio Occidental. Manejo Integrado Plagas 53:24-42.

Prabhaker, N., D.L. Coudriet, and D.E. Meyer-Dirk. 1985. Insecticide resistance in the sweet potato-whitefly Bemisia tabaci (Homoptera: Aleyrodidae). Journal of Economic Entomology 78:748-752.

Rossetto, D., A.S. Costa, M.A.C. Miranda, V. Nagai, and E. Abramides. 1977. Diferenças na oviposição de Bemisia tabaci em variedades de soja. Anais da Sociedade Entomológica do Brasil 6:256-263.

SAS Institute. 2001. SAS/STAT: Users guide. 502 p. SAS Institute, Cary, North Carolina, USA.

Schlick-Souza, E.C., E.L.L. Baldin, and A.L. Lourenção. 2011. Variation in the host preferences and responses of Ascia monuste orseis Godart (Lepidoptera: Pieridae) to cultivars of collard greens Brassica oleracea (L.) var. acephala. Journal of Pest Science 84:429-436.

Silva, M.S., A.L. Lourenção, J.A.C. Souza-Dias, H.S. Miranda Filho, V.J. Ramos, and E.A. Schammass. 2008. Resistance of potato genotypes (Solanum spp.) to Bemisia tabaci biotype B. Horticultura Brasileira 26:221-226.

Silva, L.D., C. Omoto, E. Bleicher, and P.M. Dourado. 2009. Monitoramento da suscetibilidade a inseticidas em populações de Bemisia tabaci (Gennadius) (Hemiptera: Aleyrodidae) no Brasil. Neotropical Entomology 38:116-125.

Smith, C.M. 1985. Expressions, mechanisms and chemistry of resistance in soybean, Glycine $\max \mathrm{L}$. (Merr.) to the soybean looper, Pseudoplusia includens (Walker). Insect Science and its Application 6:243-248

Smith, C.M. 2005. Plant resistance to arthropods molecular and conventional approaches. 423 p. Springer, Dordrecht, The Netherlands. 
Torres, L.C., B. Souza, B.B. Amaral, and R.L. Tanque. 2007. Biologia e não-preferência para oviposição por Bemisia tabaci (Gennadius) biótipo B (Hemiptera: Aleyrodidae) em cultivares de algodoeiro. Neotropical Entomology 36:445-453.

Valle, G.E., and A.L. Lourenção. 2002. Resistência de genótipos de soja a Bemisia tabaci (Genn.) biótipo B (Hemiptera: Aleyrodidae). Neotropical Entomology 31:285-295.

Valle, G.E., M.I. Zucchi, N.S. Stabellini, A.L. Lourenção, and J.B. Pinheiro. 2011. Estrutura genética populacional de Bemisia tabaci (Gennadius) (Hemiptera: Aleyrodidae) utilizando marcadores microssatélites. Neotropical Entomology 40:204-211.

Van Duyn, J.W., S.G. Turnipseed, and J.D. Maxwell. 1971. Resistance in soybeans to the Mexican bean beetle. I. Sources of resistance. Crop Science 11:572-573.
Vendramim, J.D., and E.C. Guzzo. 2009. Resistência de plantas e a bioecologia e nutrição dos insetos, p. 1055-1105. In Panizzi, A.R. and J.R.P. Parra (eds.) Bioecologia e nutrição de insetos: base para o manejo integrado de pragas. Embrapa Informação Tecnológica, Brasília, Brasil.

Vieira, S.S., A.F. Bueno, M.I.C. Boff, E.C.O.F. Bueno, and C.B. Hoffman-Campo. 2011. Resistance of soybean genotypes to Bemisia tabaci (Genn.) biotype B (Hemiptera: Aleyrodidae) Neotropical Entomology 40:117-122.

Winer, B.J., D.R. Brown, and K.M. Michels. 1991. Statistical principles in experimental design. $3^{\text {rd }}$ ed. 1057 p. McGraw-Hill, New York, USA. 